\title{
From Social Gospel to CSR \\ Was Corporate Social Responsibility Ever Radical?
}

Steensen, Kristian Quistgaard; Villadsen, Kaspar

Document Version

Accepted author manuscript

Published in:

Organization

DOI:

$10.1177 / 1350508419877611$

Publication date:

2020

License

Unspecified

Citation for published version (APA):

Steensen, K. Q., \& Villadsen, K. (2020). From Social Gospel to CSR: Was Corporate Social Responsibility Ever Radical? Organization, 27(6), 924-942. https://doi.org/10.1177/1350508419877611

Link to publication in CBS Research Portal

\section{General rights}

Copyright and moral rights for the publications made accessible in the public portal are retained by the authors and/or other copyright owners and it is a condition of accessing publications that users recognise and abide by the legal requirements associated with these rights.

Take down policy

If you believe that this document breaches copyright please contact us (research.lib@cbs.dk) providing details, and we will remove access to the work immediately and investigate your claim. 


\section{From Social Gospel to CSR: Was Corporate Social Responsibility Ever Radical? Kristian Quistgaard Steensen and Kaspar Villadsen}

Journal article (Accepted manuscript*)

\section{Please cite this article as:}

Steensen, K. Q., \& Villadsen, K. (२०19). From Social Gospel to CSR: Was Corporate Social Responsibility Ever Radical? Organization. https://doi.org/10.1177/1350508419877611

DOl: https://doi.org/10.1177/1350508419877611

Copyright (C) The Author(s) २०19. Reprinted by permission of SAGE Publications.

* This version of the article has been accepted for publication and undergone full peer review but has not been through the copyediting, typesetting, pagination and proofreading process, which may lead to differences between this version and the publisher's final version AKA Version of Record.

Uploaded to CBS Research Portal: May २०२० 


\title{
From Social Gospel to CSR: Was Corporate Social Responsibility Ever Radical?
}

\author{
Published online in Organization 30 ${ }^{\text {th }}$ Sept. 2019 \\ https://journals.sagepub.com/doi/full/10.1177/1350508419877611
}

\author{
Kristian Quistgaard Steensen, The Danish Evaluation Institute, Denmark \\ Kaspar Villadsen (corresponding author) Copenhagen Business School, Denmark \\ Email: kv.mpp@cbs.dk
}

\begin{abstract}
Critics lament that corporate social responsibility has failed to significantly change business practices and that it became 'de-radicalized' once embraced by corporate business management. Using historical analysis, this article reevaluates this de-radicalization thesis, questioning whether corporate social responsibility ever was as inherently radical as the thesis assumes. The article demonstrates that early corporate social responsibility was already invested with a strategy of pragmatism, an investment that traces back to a group of late 19th and early 20th century American Christian reformists, also known as the social gospel movement. They promised that industrialism would unify Christian ethics and capitalist production, thereby reconciling the conflict between profitseeking and social solidarity. The discourse they advanced already contained what would later become key corporate social responsibility components, including (1) the notion of ethical businessmen, (2) the corporation as a morally conscious being and (3) collaboration as the pathway to 'industrial peace'. Theoretically, the analysis finds inspiration in Luc Boltanski's and Eve Chiapello's thesis on modern capitalism's capacity to assimilate the critiques it faces, supplemented by Michel Foucault's fine-grained analyses of the transformation and 'tactical polyvalence' of discourse. The two positions complement each other in their assumptions regarding the dialectical relationship between capitalism/critique (Boltanski and Chiapello) and power/resistance (Foucault). Tracing the origins of corporate social responsibility's pragmatism further back in time than the conventional starting point in the 1950s casts new light on the
\end{abstract}


de-radicalization thesis. In particular, corporate social responsibility emphasizes personal ethics as the key to industrial peace, a social gospel legacy that has steered corporate social responsibility away from demands that fundamentally challenge corporate capitalism.

Keywords: Christian ethics, CSR, Foucault, genealogy, new spirit of capitalism, social gospel

\section{Introduction}

Although corporate social responsibility (CSR) has seemingly become a ubiquitous, irrefutable business concept in the global economy, it is often reported that its promises remain unfulfilled. Critical CSR scholars variously argue that the radical-transformative potential of the concept has diminished in step with its increasing use by corporate business management and thus tends to become 'de-radicalized' (Shamir, 2004). Historically oriented scholars note that in early CSR a 'trustee' relationship was proclaimed to exist between corporations and society, but that this trusteeship has been foreclosed over time. As Simon Brooks (2010) observes, when CSR emerged in the 1950s, it was justified with explicit references to morality and ethics. However, after Milton Friedman's pronouncement of a link between CSR and economic performance in 1970, such references dissipated in the decades that followed. Brooks (2010) argues that, by responding to Friedman on the premises dictated by his intervention, academics reduced CSR's critical potential: 'It is precisely the obsession in the CSR discourse with this "performance link" question that has caused us to marginalise other, more moral, considerations' (p. 605). Richard Marens emphasizes that early CSR made 'the labour question' its main concern, including wealth and income distribution, the regulation of workers' conditions, and the legitimacy of collective bargaining (see also Carroll et al., 2012: 121). These concerns were later diluted into issues of ethics and management strategy. Accordingly, Marens describes how the critical potential voiced by the earliest CSR writers became neutralized:

Most of the core concepts generated by this first generation of writers have been abandoned by their erstwhile successors, not because of any logical or empirical shortcomings, but because these earlier scholars were universally skeptical of allowing top corporate managers extensive autonomy in deciding for themselves the nature and extent of the responsibilities that they owed society. (Marens, 2008: 57) Ronen Shamir (2004) advances a similar argument about a 'de-radicalization' of the claim that corporations bear social duties to be enforced by regulation. Focusing on the present context, 
Shamir (2004) argues that CSR is a contested concept, but that influential actors 'shape the notion of responsibility in ways that diffuse its radical transformative potentials' (p. 659). Turning CSR into a 'corporate-oriented' notion serves to neutralize demands for substantial reforms and regulation of corporations, thus engendering a voluntary and self-regulatory meaning of the term that aligns with the neo-liberal logic of self-regulation (Shamir, 2004: 666-7). Finally, Ali Kazmi et al. (2016) note that CSR is unlikely to induce any major changes in corporate capitalism, as contemporary managerial literature neglects employees' needs and interests. Kazmi et al. (2016) refer to critiques in the 1960s and 1970s that fundamentally questioned the sustainability of capitalism, but they conclude that 'the initially radical critique is integrated into a new spirit of capitalism around the notion of CSR' (p. 756). Some critical scholars trace CSR's historical development, while others describe the notion's more recent integration into corporatist culture. However, these scholars are united in lamenting how CSR has lost its original, or innate, radical core and thus failed to significantly transform corporate capitalism.

This article reconsiders the 'de-radicalization of CSR' thesis (Shamir, 2004) by undertaking a historical analysis that interrogates whether CSR ever was as radical as the thesis assumes. We will argue that the word 'radical' hardly designates the early CSR discourse, if one recognizes its significant pragmatic and Christian reformist inspirations. Hence, the ostensibly radical origins of CSR find little support in the work of Howard Bowen (1908-1989), widely regarded as CSR's 'founding father' (Bowen, 2013 [1953]). In fact, we will suggest, first, that early CSR was already invested with a strategy of pragmatism or 'de-radicalization' and, second, that one can understand this investment by recovering 'the historical conditions of emergence' (Foucault, 2002: 48) from which CSR arose, including a distinct social critique voiced by American Christian reformers in the late $19^{\text {th }}$ and early $20^{\text {th }}$ centuries. These Christian reformers, also known as the social gospel movement, advanced a discourse on 'industrial peace' and collaboration - a forerunner to modern CSR, so far largely ignored by CSR scholars.

In this article, we will demonstrate that social gospel texts already contain key CSR components, such as the notion of ethical businessmen, the corporation as a morally conscious being, and collaboration as the pathway to industrial peace. This Christian-inspired social critique neither incited revolution nor sought to overturn industrial capitalism, but rather strove to reform it from within by calling for people to shun narrow self-interest and aspire to be of 'service to society'. 
This social gospel ideal of 'service' overshadowed issues of redistributive justice and regulation, for which reason industrialists felt that it 'looked like an extremely attractive answer to the problems of power and social irresponsibility' (Carroll et al., 2012: 110). Carroll et al. (2012) conclude that 'most reform took place within the framework of free-market capitalism' (p. 100), a historical development that speaks to the broader debate on the intricate relationship between modern capitalism and social critique.

Luc Boltanski and Eve Chiapello (2005) explored this relationship in their influential book The New Spirit of Capitalism (NSC), a work that examines how modern capitalism has continuously transformed itself by assimilating the critiques directed against it. Although NSC begins with a reference to Max Weber's (1905) famous thesis on Protestant ethics and the spirit of capitalism, Boltanski and Chiapello (2005) eschew the post-Weberian debate regarding Protestantism's specific influence on the development of capitalism, focusing instead on Weber's assertion that 'people need powerful moral reasons for rallying to capitalism' (p. 9). This might be why they only briefly mention that social critique is often based on 'themes inspired by Christianity' (Boltanski and Chiapello, 2005: 38), without pursuing this observation. In this article, we explore Protestantism's Influence on capitalism by examining the connection between the social gospel and the emergence of CSR.

In Boltanski and Chiapello's analysis, modern capitalism is a hollow spirit, devoid of substantial values by which to justify its own order and therefore depending on external sources for its moral values. They characterize modern capitalism in terms of its capacity for assimilation and transformation, which is precisely what makes the capitalist system so tenacious (Boltanski and Chiapello, 2005: 27). In productively integrating critiques of the capitalist order, the spirit of capitalism simultaneously 'legitimates and constrains the accumulation process' (Boltanski and Chiapello, 2005: 24). When critiques are adopted in capitalist production, they constrain pure profit maximization while also justifying (and hence sustaining) capitalism itself. According to Boltanski and Chiapello (2005), to succeed, capitalism must be justified at both an individual and a collective level: 'the arguments that can be cited to bring out not only the advantages which participation in capitalistic processes might afford on an individual basis but the collective benefits, defined in terms of the common good' (p. 4). We shall show that the social gospel embodies such a duality, offering both individual and collective justifications for participating in 
industrial capitalism.

NSC extends earlier works by Boltanski and Thévenot (1991) on how different social orders, 'orders of worth', constitute particular regimes of critique and justification. In this framework, what can be justified as worthy or 'the common good' and what can be criticized as illegitimate is integral to each social order. As such, no trans-historical foundations for critique exist (Parker, 2013: 130), so each order must be criticized on the basis of its own justifications. Critique is thus inherently ambiguous, since it must rely on the normative premises of the system criticized. Boltanski and Chiapello (2005) write: 'Even in the case of the most radical movements (critique) shares "something" with what it criticizes. This stems from the fact that the normative references on which it is based are themselves in part inscribed in the world' (p. 40). The idea that forms of justification, including criticism, cannot be 'inherently critical', insofar as they are always immanent to their context, broadly resonates with Michel Foucault's conception of power.

Foucault (2014) insisted that power is always 'reversible', since resistance against domination can itself begin to constitute a new form of domination, and hence no form of power has 'intrinsic legitimacy' (p. 77). Foucault elaborated on the instable and reversible character of power in his conception of the 'tactical polyvalence' of discourse. The term indicates that a statement's strategic function ensues from the statement's specific relationship to other statements. Discourse, wrote Foucault (1978), is 'a series of discontinuous segments whose tactical function is neither uniform nor stable' (p. 100). The notion of a statement's tactical polyvalence offers a focal point from which to explore how 'critical' or 'progressive' conceptions might become rearticulated in a new discourse, thus becoming related to other statements whose meaning and strategic function thus change. While our analysis of CSR's historical emergence is inspired by Boltanski and Chiapello's overall assimilationnist thesis, we use Foucault's fine-grained approach to discourse to examine this emergence more closely.

We believe that exploring CSR's historical indebtedness to Christian social ethics will cast new light on the CSR de-radicalization argument. We thus wish to flesh it out by tracing CSR's assimilation and de-radicalization further back in time. More specifically, we will trace three constructs in the CSR discourse:

1. The businessman as an ethical subject

2. The company as a morally conscious being 
3. Industrial peace as being achieved through pragmatic collaboration

Together, these notions can be said to constitute a de-radicalizing strategy that, as the below analysis will demonstrate, was already visible in social gospel writings. In the concluding discussion, we consider how CSR's Christian pre-history casts new light on the question of whether CSR ever was as radical as the de-radicalization thesis assumes.

\section{CSR's Christian roots}

Although scholars have addressed the connection between Christian social critique and business ethics (Abend, 2014; Acquier et al., 2011; Carroll et al., 2012; Davenport, 2008; Hall, 1992; Heald, 1970; Moura-Leite and Padgett, 2011), research has been sparse on the specific historical links between CSR and the social gospel movement that formulated what could be called early CSR themes. By focusing on the discursive conditions of possibility for CSR, our study distinguishes itself from important historical works on the relationship between Christianity and capitalism in North America. Gabriel Abend (2014), for example, traced the 'moral background' of business ethics, which includes Protestant values and ideas. Inspired by Heidegger, Abend asserts that this moral background is not directly observable, constituting a set of tacit assumptions that allow actors to define ethical questions and make judgements. Following Foucault, our study does not search for such a deep background of meaning since it assumes that discursive regularities and transformations are directly observable in the textual archive. A significant study done by Stewart Davenport (2008) examines the relationship between Christianity and capitalism through the lens of specific Christian elites and their differing attempts at reconciling their faith with capitalism.

Our study, however, is not concerned with the numerous factions in the history of American Christian reformism, but rather zooms in on a select group of social gospel writers in order to trace their articulation of early CSR concepts. Finally, Peter Dobkin Hall (1992) explored the historical institutionalization of the American trusteeship tradition, finding that Catholics and Protestants differed in their capacity for organizing. Our study largely eschews such questions of institutionalization and organization, focusing instead on an emerging field of CSR discourse and how objects were constructed and concepts rearticulated. However, we build on Abend's, Davenport's and Hall's studies in the sense that we explore a specific phase in the evolving interrelation of Christian social reformism and business ethics. The ideas and concepts of the social gospel can thus be situated 
as part of the historical interplay between Christianity and capitalism variously explored in the above-mentioned studies.

An examination of the historical archive reveals that a discourse asserting the progressive role corporations can play in society and human history when they reconcile self-interest and the public interest had already emerged around 1900. At this time, a variety of 'progressive' reformers, most with Christian backgrounds, debated the urgent challenges posed by industrialization in North America. These progressives sustained the 19th century belief in progress as inherent to human history, although insisting that progress results from an active tending of society (Carroll et al., 2012: 92). The social gospel was an important movement in the progressive period, offering a resolution to the dichotomy between self-interest and public interest by promising a concomitant 'redemption' of individuals and society. The movement parallels Chiapello's (2012: 71) notion of 'conservative criticism' of capitalism, which appeared in the mid-19th century and focused on moral disorder, the fostering of personal virtue, and affection between the classes. However, Chiapello's typology does not include religious justifications. Social gospellers spoke of 'a system cooperation', 'partners in business' and 'the Christian law of love', also proclaiming the need to build industrial relations upon a brotherly basis' and 'arguing that industrialists were administering a public trust 'bound to benevolence, as well as enterprise'.

Our analysis focuses on a distinct textual archive exploring how social gospellers and progressives debated industrialism's potential for becoming a social order based on love, cooperation, and solidarity. The United States forms the backdrop for this study, because most agree that CSR first appeared as a distinct concept in early-1950s North-American management literature (Carroll, 1999; Gorrel, 1988; Moura-Leite and Padgett, 2011). We do not exhaustively cover the historical interaction of Christian ethics and business activity, which dates at least as far back as the very origins of Christianity (Davenport, 2008: 216), but we rather focus on a specific era from 1870 to 1920 which was heydays of the social gospel.

\section{Discursive formations}

Inspired by Foucault's genealogy, this article sets out to recover the discursive conditions that allowed CSR to emerge as an established business concept. Foucault (2002) wished to describe the 'conditions of historical appearance' (p. 48) that made specific statements at particular moments possible, 'a body of anonymous, historical rules, always determined in the time and space' 
(Foucault, 2002: 117). For Foucault, to analyse discourse as an independent object of study, one must carve out a space irreducible to the speaking subjects or semantic structures. Accordingly, texts, concepts and statements can only be understood within a field of statements that Foucault termed a discursive formation: The system of references, or interdependencies, 'on the basis of which coherent (or incoherent) propositions are built up, more or less exact descriptions developed, verifications carried out, theories deployed' (Foucault, 2002: 200). Notably, a discursive formation is not an immobile structure that forces the speaker to submit to a set of fixed rules. The principles of formation allow new utterances that presuppose, support, anticipate or contradict already existing utterances within the same field of discourse.

Objects like madness, the state or, in our case, CSR are not stable entities, for they can only be described 'by relating them to the body of rules that enable them to form as objects of a discourse and thus constitute the conditions of their historical appearance' (Foucault, 2002: 47-8). For example, we will see that gospel writers constructed 'the object' of their discourse, industrial peace, with distinct characteristics and systematically related that object to subjects by mobilizing the concept of 'new ethics'. This analytical approach neither establishes direct causalities between historical events nor infers explanatory relations between historical actors, but rather describes 'continuities' between different discourses and speakers, recovering parallel uses of concepts, normative premises, and explanatory models.

In this context, the discursive formation under scrutiny is the discourse on industrial peace formulated by social gospel advocates and progressive reformers in the late 19th and early 20th centuries. Rodgers (1982) observes that although the progressives hardly formulated a coherent ideology, they shared an identifiable constellation of ideas, which he designates 'languages of discontent' directed against 'arbitrary, unregulated individual power' (p. 123). The social gospel protagonists critiqued the Spencerian idea of social evolution through unbridled competition, proclaiming that industrial society contained the seeds for collaborative fellowship and solidarity. The following analyses rely on key works by three thinkers who either were self-proclaimed members of the social gospel movement or dialogued closely with it: Washington Gladden, Richard T. Ely and Jane Addams. They are considered among the chief protagonists of the social gospel's characteristic Christian reformism. Furthermore, they all engaged themselves with industrial relations and corporations' social responsibilities. We analyse selected writings published in the period 
1876-1933 that centre on labour issues and how to achieve industrial peace. We then make connections to early CSR writing, primarily Howard Bowen's key work, Social Responsibilities of the Businessman (SRB).

A discourse analysis based on only a few writers, risks requiring psychological and biographical references to explain the authors' texts, thereby reintroducing the constitutive subject into the analysis. Foucault (1977) discussed this problem of 'the author's' status, considering how to include influential authors in discourse analysis without restoring 'the theme of an originating subject' (p. 137). He explained that analysing discursive layers did not mean that the author subject should be entirely abandoned. Instead, 'it should be reconsidered ... to seize its functions, its intervention in discourse, and its system of dependencies' (Foucault, 1977: 137). In the development of discourse, some authors may play particularly important roles as they rearticulate the rules of formation or initiate new concepts, theories or even disciplines. Such figures, said Foucault (1977), are able to open a new style of discourse, occupying a 'transdiscursive' position from which 'new books and authors can proliferate' (p. 131). Such authors 'are unique in that they are not just the authors of their own works. They have produced something else: the possibilities and the rules for the formation of other texts ... an endless possibility of discourse' (Foucault, 1977: 131). Our selected authors can be termed 'transdiscursive' insofar as they rearticulated primordial Christian notions in initiating a discourse on industrial peace that outlined industrialists' social responsibilities.

\section{The perfection of society}

The term social gospel conveys several meanings. First, it designates a movement within Protestantism; second, the influence of Christian faith on the social order; and, third, social as opposed to individual salvation (Gorrell, 1988: 4). The social gospel movement was central to the American progressive era, typically identified as spanning 1870-1920 (Handy, 1966). Social gospellers were concerned with the problems of rapid industrialization, as the growing scale of corporations blurred the line between activities affecting the public interest and private matters (Carroll et al., 2012: 106). Social gospel advocates cautioned that soulless consumption, ruthless competition and class warfare were rising in industrial cities, and yet they believed that industrialism could be imbued with a Christian ethics of love.

Social gospellers contested the ideas of social Darwinists, who advanced a competition-based 
doctrine of human progress inspired by Darwin's theory of 'survival of the fittest' (Eddy, 2010). This debate centred on the question of mankind's basic nature, that is, whether man was made for warfare or solidarity, for consumption or spiritual development, for competition or cooperation (Eddy, 2010: 22-4). The social gospel cautioned against 'brutal class war', insisting that human misery could be ameliorated through social reform and cooperation based on Christian ethics (Handy, 1966: 3-4).

Inspired by Protestant postmillennial ideas, social gospellers believed that society's salvation did not entail the resurrection of a Messiah figure, but was already happening through human efforts inspired by Christ's teachings (Quandt, 1973: 391). Postmillennialists assumed that the Kingdom of God will gradually be realized when justice, peace and love pervade all society, including secular institutions. Significantly, the way social gospellers interpreted postmillennialism impelled them to amend industrial capitalism incrementally, 'from the inside', which helps explain their desire to reform rather than disrupt capitalism while bringing about the Millennium.

The social gospel emphasized secular institutions, including education, culture, science and administration, as the means of perfecting society. They still envisioned that this perfection would occur through the diffusion of Christian values, although references to a transcendent God decreased, while calls for human efforts to realize the Kingdom grew (Quandt, 1973: 394-6). The social gospel discourse revolved around a construction of 'man's' activity as necessary for society's perfection and for the progression of humankind. In this discursive construction of subject and object, the subject's actions in regard to others create an object that is much greater, one that ultimately constitutes humanity's progressive history. As the analyses of Gladden, Ely and Addams will show, the social gospellers intertwined Christian doctrines with modern ideas of progress, although they emphasized inherent human kindness as the driver of social harmony, a belief fundamental to the construction of their key discursive object, industrial peace.

\section{Washington Gladden: the system of cooperation}

Washington Gladden (1836-1918) served as the pastor of the First Congregational Church of Columbus, Ohio, from 1882 until his death. Gladden also offered his expertise on social Christianity to The Men and Religion Forward Movement, initiated in the early 1910s by prominent businessmen such as John D. Rockefeller. The movement aimed to promote bible study, 
community extension and social service as a means of ensuring that Christian values permeated all daily affairs (Gorrell, 1988: 156-61).

His numerous sermons, lectures and publications on social Christianity made Gladden 'the father of social gospel' (Gorrell, 1988: 302). Focusing his reformist efforts on the conflict between capital and labour, Gladden believed that God's reign on earth would be fully realized when the 'Christian law of love' pervaded industrial society (Handy, 1966: 7; Quandt, 1973: 397). To support this conviction, Gladden asserted that God unified economy and ethics, and that industrial actors had no right to separate them.

Addressing the capital-labour conflict, Gladden (1876) noted that history reveals three systems that bring the two parties together: the system of slavery, the wage system and the system of cooperation (p. 38). He believed that industrial society was approaching the cooperative system 'by and by', implying that the labourer and the capitalist soon would develop a comprehensive industrial partnership based on profit sharing (Gladden, 1876: 45, 48). However, the system of cooperation would not be realized until 'the Christian law of love' replaced competition - the bedrock of the wage system (Gladden, 1876: 48). Conflict would continue to tear the relationship between capital and labour as long as it was premised on a competitive wage system (Gladden, 1876: 40). 'Industrial partnership' was to guide the transition from the wage system to the system of cooperation (Gladden, 1876: 48). In the system of cooperation, labourers would be given a financial interest in the business, thus gaining a stipulated percentage of company profits in addition to their wages. The creation of industrial partnership, argued Gladden (1894), would harmonize the interests of capital and labour in a 'moral organism', which would be 'a community of purpose and endeavour' (p. 232). Gladden envisioned workers' proprietary interests as being integrated into their work (Christiansen, 2015: 31) - an idea never widely realized, but that presages later CSR notions of employees' acquiring a 'sense of ownership' through delegation, company stocks or profit sharing.

Gladden's reform programme did not fundamentally attack corporate decision-making power, as he maintained that private industries, being profit-driven, were essential for progress. In Tools and the Man: Property and Industry under the Christian Law (Gladden, 1894) Gladden reassured industrialists that industrial partnerships did not render industrial leaders redundant, since his vision still required leadership. The natural leaders would 'come to the front' when the 'factitious 
distinctions' between labourer and capitalist were swept away (Gladden, 1894: 240). Gladden (1894) reasoned that the cooperative principle would soon rule, and that mankind's progress would make men compete less and collaborate more (p. 176). The most important lesson for industrialists and labourers was that they were neighbours:

Having learned this lesson, they may well remember that there is one law which will bring order out of this it is the simple, old-fashioned law, 'Thou shalt love thy neighbor as thyself'. (Gladden, 1894: 145)

Proclaiming the Christian law of love in industrial relations, Gladden refused to side with socialists or laissez-faire liberalists. He criticized liberals for neglecting the environment in their celebration of the individual and socialists for neglecting the individual. Instead, he advanced 'a better society to live in, and better men to live in it' (Gladden, 1894: 306). A perfect man in a perfect society was the twofold end of Christianity, which could never be fulfilled if these two purposes were separated (Gladden, 1894: 1). Gladden (1894) argued that the most Christian and valuable thing one could do was to have a business that both employed a great many workers and supported them in attaining more fulfilling lives:

Faint signs are even now visible in our sky of the dawning of day when business shall be to many men the high calling of God and the medium through which unselfish spirits shall pour out their energies in ministries of help and friendship. (p. 307)

This sense of 'stewardship' belonged to 'gentlemen capitalists' (Gladden, 1876: 186), which broadly resonates with the CSR principle that responsible managers ensure the welfare and selffulfilment of their employees.

In another major work, Social Facts and Forces, Gladden (1897: 90) discussed how the mutually reinforcing interplay between individual and society would install a moral compass in conscienceless corporations. Defining the corporation as 'a body consisting of one or more natural persons, empowered by law to act as an individual, and continued by a succession of members', Gladden (1897) stressed that 'the corporation is not, like the saloon, an unmitigated evil, that ought to be discouraged by taxation; it is a great blind Samson that needs guidance' (pp. 83, 103). This metaphor of the corporation as a persona ficta in need of a tutor dates back to at least the 13th and 14th centuries (Canning, 1980). The need for guidance arose from the soulless nature of the corporation - an aggregation of individuals empowered by law to act as an individual and yet lacking a conscience. There could be no moral reciprocity between man, a being with a conscience, and a 
corporation, a being without one, if the corporation blocked the interactions of consciences (Gladden, 1897: 92). Morally improved industrial actors would equip corporations with a soul and sound an alarm 'whenever it becomes evident that they are getting to be gigantic egoisms, that they recognize no relation to the community but that of a predaceous animal' (Gladden, 1897: 113). Nevertheless, Gladden (1897) cautioned that interference in corporations was unwarranted if their conduct indeed evinced their souls, in which case they would 'be honored and praised and rejoiced in, as the ministers of God' (p. 113).

In summary, Gladden articulated key components of the social gospel discourse, including the promise that the proliferation of Christian sentiments, 'the Christian law of love', would cure the pathologies of industrialism. This process would serve to reinvigorate the corporation as a morally conscious being. In calling corporations 'soulless', Gladden echoed a widespread critique of corporate soullessness in late 19th century American society (Bell et al., 2012). The law empowered the corporation to act, Gladden asserted, but unless equipped with a moral compass it would lack a morality to guide these actions. He therefore envisioned a corporation that transcended legal and contractual bonds, an 'over-soul' that allowed 'the interactions of consciences'. Gladden's critique of corporate soullessness foreshadows later CSR notions that construe the corporation much like an individual, thus rendering it praiseworthy and blameworthy like a real person. Gladden presaged the assumption that corporations must transcend narrow profit motives to benefit 'multiple stakeholders' and pursue higher ends like human growth, sustainability, social rights and freedom. It has been argued that organizations oriented at authenticity, meaning and higher consciousness have less risk of ethical misconduct (Bell et al., 2012: 426). Gladden argued, as much recent CSR literature, that regulatory constraints do not ensure the pursuit of higher purposes, which rather prosper when corporations adopt a voluntarist CSR.

\section{Richard T. Ely: apostle of social reform}

Although an economist, Richard T. Ely (1854-1943) became one of the most influential members of the social gospel movement. As a political economy Professor at John Hopkins University, a prolific writer and a social reform advocate, Ely reached beyond academic circles to become a significant lay spokesman of the social gospel (Fine, 1951: 599-601). He rejected the division between the sacred and the secular, insisting that economics and ethics were inseparable and that 
the Church had a duty to infuse Christian ethics into all earthly matters (Fine, 1951: 602, 605). Ely emphasized the importance of social reform as the means to spur the moral progress of individual and society (Rader, 1966: 72). In The Social Law of Service, Ely (1896) argued: 'Surely much individual effort, much teaching and preaching, are required to make men good ... but the law has established a fundamental condition of true morality and goodness' (p. 183). Like Gladden, Ely (1889) believed that the industrial world faced a severe social crisis due to the increasing antagonism between labour and capital, 'the most important, the farthest and deepest reaching crisis known to human history' (p. 137). Proper social reform was necessary to mitigate the evils of competition through raising its moral and ethical foundation (Ely, 1903: 97). From observing industrialists' actual actions, Ely concluded that claims regarding a benign capitalism must be critically tested, since they did not always reflect workers' realities. He thus put issues akin to 'transparency' and 'accountability' on the agenda.

In his vision of a moral economy, Ely (1896) referred to Aristotle and Plato, who denied the accumulation of riches as an end in itself, emphasizing instead how business could facilitate the highest physical, mental and spiritual development of man (p. 148). Ely (1896) asserted that such an equilibrium between business development and spiritual growth was already coming: 'This world will become a happier and happier world as time goes on, for the coming of the kingdom means the subjugation of the entire world to Christ' (p. 89). Ely (1896: 146) believed that the mutually reinforcing interplay between the improvement of character and sound industrial regulation would gradually extend the range and depth of ethical obligation:

Day by day the phrase, 'All men are brothers', comes to mean more and more, and the time is surely coming when it will ethically mean as much in the world at large as once it did in the village community; and when that time comes no decent man will any longer advocate the legitimacy of the universal sway of sharp practice and hard bargaining. Men will then try to put all business relations upon a brotherly basis. (Ely, 1896: 147)

The connection between individual growth and general welfare was crucial to Ely (1889), who echoed Gladden's belief that Christ's gospel is at once individual and social (p. 149). Ely also held a similarly tempered stance regarding political reform.

In Studies in the Evolution of Industrial Society (1903), Ely presented a pragmatic reform programme in which individual and social regeneration was achieved within the existing social order. Rejecting radical alternatives like socialism and anarchy, he found that the existing industrial system 
had 'great vitality' and was 'sound in its most essential elements' (Ely, 1903: 464). For Ely, 'anarchy' could only mean tyranny and despotism, as it elevated liberty to an absolute ideal over social authority and common service. Socialism, for its part, failed to provide a sufficient notion of industrial liberty and too greatly limited free choice (Ely, 1903: 464). Invoking the apostle Paul's message, 'we are members one of another', Ely (1903) located the true ideal of industrial society midway between these extremes in 'the principle of social solidarity', which required 'wisely executed regulation of economic relations' (pp. 422-3).

Like Gladden, Ely (1896) argued that freedom was not guaranteed by contracts, but hinged on the regulation of industrial relations. 'Free contract alone', he asserted, 'can only result in a degrading dependence of some men upon others, and consequently social degradation. On the other hand, through regulated association come freedom and individuality' (p. 99). While some industrialists might accept social responsibilities, not all necessarily would, in which case workers would be at the mercy of company owners, and Ely was particularly critical of this arbitrariness inherent in an unregulated capitalism with centralized power (Christiansen, 2015: 38). Compared to later CSR debates, Ely's view resembles a pro-government regulation stance on companies' obligations, rather than relying on voluntary 'compliance'.

Regulating industrial relations did not, however, imply an end to competition. Instead, Ely (1903) described competition as 'a permanent feature of human society' (pp. 144-5), although arguing that social control was required to ensure that the ends of competition were ultimately association and cooperation, not monopoly. Indeed, Ely (1903) was convinced that, with regulation, competition could fulfil its altruistic potential, engendering 'rivalry in the service of self and other selves - rivalry in the upbuilding of the ideal man in the ideal society' (p. 149). This was a processual notion of freedom, since Ely (1903) emphasized that liberty was not the product of a constitution but a state achieved by individuals working together, arising 'not all at once, but slowly as the result of a long-continued and arduous process' (p. 423). Conceiving of freedom as process, Ely (1889) argued that every human has powers ripe for cultivation, as 'each person ... accomplishes his end when these powers have attained the largest growth which is possible for them' (p. 124).

In summary, Ely believed that careful social reforms would raise individuals' moral level and, eventually, bring about The Kingdom in industrial society. In Foucauldian terms, he discursively 
constructed the key object, industrial society, as neither a legal nor an economic order but rather as a transcendent organism held together by sympathetic sentiments. Ely shared other social gospel advocates' view that the changes needed in industrial society would essentially arise from individuals' ethics. The way forward therefore entailed not so much a direct confrontation with society's existing power structure but more a pragmatic collaboration supported by moderate regulation. One premise for this pragmatism, characteristic for the social gospel movement, was Ely's notion of freedom as processual (rather than substantial). As he saw it, freedom was not constructed as an end-state or a set of rights, but rather achieved through learning ensuing from people's collaborative interaction. Taking such a position, the social gospellers were often inspired by the pragmatist thinking of contemporaries like William James and John Dewey. While these pragmatists did not contest the pursuit of higher ends, they argued that the individuals concerned needed to test truth and moral values for their usefulness. The social gospel could be said to discursively 'resolve' the tension between its reliance on certain ultimate values and the pragmatic premise of values' embeddedness by rearticulating polyvalent concepts (Foucault, 1978: 100) like 'brotherhood', 'social redemption' and 'the Christian law of love'. Such polyvalence also allowed social gospellers to diverge in their precise rendering of these terms and their implications for corporations and regulation.

To which extent abstract and universal values should be specified in codes of conduct for corporations' business practices has been a reoccurring question in modern CSR discourse. While more research is required to trace the schism between abstract notions and local business practice in CSR over time, CSR scholars have recently drawn on American pragmatism to handle 'the paradox of CSR standards' (Colle et al., 2014). Instead of insisting on rigid compliance with CSR standards, these scholars argue that standards need to be continuously interpreted in and adapted to corporations' local contexts. Referring to William James (1842-1910), an influential pragmatist in the progressive period, they contest the utility of a 'fixed truth' and 'ex ante' defined CSR criteria, instead emphasizing the importance of learning, 'developing new beliefs, and changing existing ones' in the development of CSR standards (Colle et al., 2014: 189). The pragmatist strategy, already evident in Ely and other social gospellers, thus allows CSR writers to temper the demands of ultimate CSR principles, 'adjusting' them to specific business practice contexts. 


\section{Jane Addams: social ethics}

Jane Addams (1860-1935) has received various titles, including those of early social worker and sociologist, pioneer in pragmatist research, feminist and Christian activist. She founded a social settlement, Hull House, in Chicago to breach the growing class divide by providing a place of integration and cultural uplift. She shared key values with the social gospel movement, and she engaged with issues like public health, child labour, industrial disputes and political reform. Like Gladden and Ely, her engagement in industrial relations took a mediating approach, insofar as she associated herself with both employers and employees, without ultimately taking sides in conflicts (Heald, 1970: 23).

Addams (1902) famously advanced the notion of 'new social ethics', a force that would regenerate industrial society by imbuing social relations with fellowship and collaboration. The fastpaced development of industrialism created interdependencies between individuals from different cultural, religious and national backgrounds. At the same time archaic morals and authorities were increasingly called into question. Addams believed that this development required individuals to assume new responsibilities that extended beyond self-fulfilment and partisan interests, a call that was being answered across key institutions, including family, industry, philanthropy and administration. Addams' (1902) first book, Democracy and Social Ethics, described how this new social ethics emerged in the industrializing city, providing numerous examples of people who developed new practices and values as they tackled the moral challenges of the time. Foregrounding ethics as an essential component of regenerating industrial society, Addams' writing paralleled the social gospel discourse on industrial peace as articulated by Gladden and Ely.

Like Gladden and Ely, Addams eschewed both socialism and laissez-faire liberalism, arguing that compromise and collaboration could better ameliorate social problems. In her assessment, liberal rights thinkers and socialists were equally rigid, propagating hostilities instead of compromise. The times, she believed, called for a new spirit that was oriented towards 'the larger whole' embodied in an industrial society undergoing a difficult transition. These aspects reveal a continuity, in Foucault's sense, between Addams' writings and the social gospel discourse in her construction of society as an 'over-soul', a continuity that transcends individual self-interest and class interests (Villadsen, 2018).

When it came to industrial disputes, Addams (1930) was sympathetic to both labourers and industrialists, through her writings repeating her appeal for amicable collaboration in industrial 
relations and asserting that neither side should achieve dominance, as this would create a 'constant struggle between organized capital and organized labour with the result in trade-union tyranny, and in others, employers' tyranny' (p. 462). Addams did not find labourers' struggle for better wages through unionization illegitimate. Labour unions were bound to fight to improve workers' conditions, but Addams (1895) feared they would descend into primitive 'class warfare' and lose any 'all-embracing ideal' (pp. 201-2). Addams generally pursued a tempered political stance, aiming to reconcile classes rather than to eliminate class differences. The issue for Addams (1895) was to avoid violence or strikes as the means of social transformation, as she felt far more could be achieved if workers accepted the accredited means of arbitration, since then the unions 'may attain an accredited business standing' (p. 191).

In a formulation that almost presaged later CSR discourse, Addams stated that large companies could no longer act out of private interests, for public interests were deeply invested in their operations. It is claimed, Addams (1902) wrote,

that a large manufacturing concern has ceased to be a private matter; that not only a number of workmen and stockholders are concerned in its management, but that the interests of the public are so involved that the officers of the company are in a real sense administering a public trust. (pp. 1423)

In Addams' view, those industrialists who fail to recognize their greater public responsibilities cling to archaic moral codes of individualism instead of embracing the emerging ethics of collaborative management. This was 'a clash between individual or aristocratic management, and corporate or democratic management' (Addams, 1902: 139). Notably, Addams drew a distinction between the factory that has taken a 'socialized form' and a management still premised on 'individualistic ends', reflecting her general idea that material development often outpaces morality. Accordingly, Addams asserted that the new social ethics called for novel forms of association that would both respond to the conditions of industrial society and be imbued with a spirit of loving collaboration.

In sum, Addams' writing offered the coming of a new social ethics as the solution to class conflict and disruptive industrialization by turning social relations into 'friendly collaboration'. She thus spoke about the need to foster 'higher moral and intellectual qualities' aligned with industrial society's need for collaboration (Addams, 1899: 340). In Foucault's terms, she constructed the subjects as carriers of a nascent social ethics that would steer them towards sympathetic collaboration instead of self-gratification and class war. Addams' subject of new social ethics resonates with 
Foucault's analysis of the Christian subject as someone who confirms the relationship of obedience principally by renouncing his or her own will: 'What does the absence of path of passions, mean for Christianity? Essentially it means renunciation of egoism, of my own singular will' (Foucault, 2007: 178).

Addams (1905) criticized the state for not caring enough about citizens' welfare, education and spiritual needs and instead restricting itself to a legal-punitive function: 'We have, therefore, a municipal administration in America which is largely reduced to the administration of restrictive measures' (p. 428). The state must shed its restrictive role to begin fostering citizens who enact social ethics in their social relations, that is, shape them in terms of how they constitute themselves as subjects. Notably, in Foucault's (2007) analysis of the Christian tradition as a backdrop for modern welfare, 'pastoral power' had the dual goal of saving 'omnes et singulatim': 'to save the whole and to save each' (p. 169). In Addams' vision, industrialists as well as workers would become ethical subjects who, by interacting 'social-ethically', would forge a major social redemption.

\section{The social gospel of CSR}

In the decades following the progressive period, explicit references to Christian ideas became sparser among early writers on the responsibilities of business. Nevertheless, the social gospel discourse and subsequent writers display some continuities in terms of the concepts chosen, how subjects and objects were constructed, and the political implications of their statements. We reiterate that a discursive formation is not an immobile and constraining structure, insofar as it allows new utterances that presuppose, support, anticipate or contradict already existing ones (Foucault, 2002: 200). Even if later contributors to the nascent discourse on CSR were typically less hopeful about the promise of industrial peace, they reiterated the appeal to industrial actors to shed their partisan interests, find their inherent goodness, and work for the benefit of the greater whole. As 'the father of CSR' (Acquier et al., 2011; Carroll, 1999), Bowen displays several continuities between the social gospel and early CSR writers' visions in his work. Discussing the emerging 'doctrine of social responsibility' in his landmark book, SRB, Bowen (2013 (1953)) outlined the seminal definition of CSR as 'the obligations of businessmen to pursue those policies, to make those decisions, or to follow those lines of action which are desirable in terms of the objectives and values of our society' (p. 6). 
Bowen's writing on CSR is of particular interest here, as Bowen can be considered a 'transdiscursive author', to use Foucault's (1977: 131) term. Apart from his own work on businessmen's social I responsibilities, Bowen also applied his CSR conception to produce a text that opened up for a proliferating discourse. Bowen partly achieved this by rearticulating a series of Protestant notions to address the problems of rapid industrialization and labour conflicts. As the following analysis displays, the continuities between social gospel doctrines and Bowen's work are several. Few CSR scholars have noticed that $S R B$ was a volume in a series entitled Christian Ethics and the Economic Life, commissioned by the Federal Council of Churches (FCC) and funded by the Rockefeller Foundation (see, however, Acquier et al., 2011: 613). According to the historian Christopher Evans (2017: 107-8), the creation of the FCC was the key institutionalization of the social gospel. In 1912, 4 years after the FCC was established, it released Social Creed of the Churches, which reiterated social gospel principles, including the dictum that the individual cannot be redeemed without the redemption of society, and vice versa:

With the growth of our population, and the resultant need for greater economy in the use of our natural resources, the spirit of cooperation is likely to increase so that the patriot of the future is likely to become the man who has a well-developed sense of collective responsibility. (Ward, 1912: 175)

Furthermore, the FCC extended the irenic progressivism of the social gospel, echoing the pragmatic stance of social gospel advocates like Gladden and Ely: The church should not supersede other reform agencies but influence them through moral appeal and example (Evans, 2017: 109). Although evident Although evident throughout SRB, Bowen's affiliation with the FCC is most prominent in chapter 5 , Protestant Views of the Social Responsibilities of Businessmen, in which he deduced businessmen's social responsibilities from Christian ethics, drawing on a comprehensive archive of Protestant literature from the first half of the 20th century. Bowen's (2013 [1953]: 231-4) explicit references are scant, but Appendix A in his book holds a complete bibliography of the literature on which the chapter is based. Consulting this archive of Protestant literature reveals clear parallels between Bowen's seminal conception of CSR and the social gospel. Notably, the FCC is the most frequent source of literature cited in Bowen's arguments. Bowen's (2013 [1953]: 231) references to the FCC (1932) include its updated social creed, Social ldeals of the Churches, which requests that churches work to subordinate the profit motive under Christian principles of social well-being.

Another of Bowen's FCC (1947: 16) references, Pronouncement on Religion and Economic Life, 
similarly acknowledge that profits 'are characteristic of a money economy and are defensible, subject to proper methods of accumulation and distributing them', but that 'Christians must be actuated more largely by a service motive than by a profit motive'. Bowen additionally cited Christianizing the Social Order (1914) by Walter Rauschenbusch, a central social gospel theologian and FCC figure.

From this Protestant archive, dominated by the FCC and its affiliates, Bowen (2013 [1953]) discerned 16 principles that he synthesized into a Protestant doctrine to guide the businessman 'who wishes to discharge his Christian duty' (p. 39). Several of these principles echo key ideas of the social gospel, as reiterated in the FCC's social demands to the churches and evident in Bowen's proclamation: 'The businessman should be actuated by the motive of serving society rather than maximizing profit as the sole end of enterprise'. Affirming the idea of human growth, Bowen (2013 [1953]) proclaimed that 'the businessman should be imbued with respect for the dignity and essential worth of all men', which entailed his refraining from any discrimination and ensuring that all employees' personal development is 'commensurate with their potentialities' (pp. 39-41).

Overall, Bowen's writing throughout SRB resonates with the social gospel discourse on industrial peace, perhaps most noticeable in Bowen's construction of industrialism as peaceful and the businessman as an ethical subject. Introducing the idea of the voluntary socially responsible businessman into the debate on the appropriate balance between freedom and regulation, Bowen, like Gladden, Ely and Addams, drew his inspiration from Christian ethics, but also adopted the social gospel's generally pragmatic attitude to industrialism (Acquier et al., 2011: 613). Thus, Bowen's (2013 [1953]: 25-7) introduction of social responsibility as a third way between the laissez-faire of liberalism and the doctrine of socialism has a familiar ring. Bowen, like Ely, rejected the dichotomy between egocentrism and altruism, advocating an individual self-determination tempered by concerns for social welfare:

Because ethical problems frequently arise when individual and social interests are in conflict, the assumption is often made that ethical conduct invariably requires suppression of self-interest or sacrifice by the individual. This notion is, of course, false. Throughout great areas of life, self-interest . .. is, or can be made to be, consistent with the social interest. (Bowen, 2013: 14)

According to Bowen (2013 [1953]), a major task of economic engineering was to ensure consistency by establishing 'social arrangements under which individual self-interest and the social interest become, so far as possible, mutually compatible' (p. 14). Bowen's conceptualization of 
CSR encapsulated such an arrangement of compatibility between individual and social interest. He stressed that the concept of CSR 'should not be made the vehicle or the excuse for an attack on the profit motive, or on profits as such' (Bowen, 2013 [1953]: 143). Instead, it would be a source of 'profound satisfaction' when the private and the social interests of business were found to be consistent, 'because action in the social interest is doubtless more reliable when it is reinforced by the private interest' (Bowen, 2013 [1953]: 68). Emphasizing that the private interest of business can reinforce socially favourable actions, Bowen repeated the social gospel protagonists' belief in a reciprocity between individual autonomy and social solidarity as the route towards moral vigour (Acquier et al., 2011: 622). This was a socially integrative pathway, a responsibility comparable to social gospellers' call for sympathetic collaboration.

Several continuities have been identified between the social gospel discourse on industrial peace and the early discourse on CSR, represented by Bowen. Not only did the two discursive groupings display a pragmatic third way that combined liberalism's celebration of individual freedom with socialism's emphasis on solidarity, but they also held a parallel conception of freedom as the fulfilment of each individual's inner potential, visible in Bowen's (2013 [1953]: 40-1) emphasis on business' responsibility to ensure everyone's personal development. As noted above, Gladden, Ely and Addams' writings were guided by a reformist stance assuming that the dissemination of Christian ethics would reform, not abolish, capitalist production. The discursive construction of industrial society as pregnant with social collaboration, reiterated in Bowen's (2013 [1953]: 5-7) seminal CSR conception, constituted a discursive strategy that disqualified fundamental challenges to corporate autonomy. Another notable continuity connecting Bowen's seminal conceptualization of CSR with the social gospel was the ideal of abandoning narrow self-interest and being of service to society. Bowen integrated this ethical imperative in a nascent CSR discourse that could temper demands for governmental regulation of corporations.

Centring on Bowen as a 'transitional' author connecting the social gospel with CSR does not exhaust early CSR literature, which also includes figures like Keith Davis and William C. Frederick. However, given SRB's renown as the foundational text of CSR, bringing the work's system of dependencies to light can transform not only our historical knowledge but also the very field of CSR - 'if only through a shift of accent or of the centre of gravity' (Foucault, 1977: 136). One can shift the accent by recovering Bowen's Protestant-inspired messages, not simply re-interpreting the 
text, but engendering change in the way existing texts are read.

\section{Was CSR ever radical?}

From a Foucauldian perspective, analysing the continuities and discontinuities between the social gospel doctrine on industrial peace and Bowen's conception of CSR is intriguing, for it traces the complex emergence of a new discursive field as well as speaks to Boltanski and Chiapello's thesis on how critique transforms the spirit of capitalism.

We can now suggest that Bowen legitimized social gospel critiques of capitalism by rearticulating them in his own conceptualization of CSR, while also excluding certain critiques from his demarcation of CSR. Paying close attention to the discursive continuities and discontinuities when the CSR discourse emerged, one can argue that a pragmatic, de-radical rationality that excluded demands for radical CSR practices permeated CSR from the outset. As already discussed, Bowen adopted the social gospel's ethical imperative in his conception of CSR, but placed the belief that ethical society required government regulation outside the 'margin of tolerance'. A margin of tolerance defines the delineation of a discursive formation through the use of something it rejects (Foucault, 2002: 41). Paralleling his scepticism towards laissez-faire liberalism, Bowen was critical towards a purely voluntary and corporate-centric approach to CSR. However, in SRB Bowen never sought to question capitalism, but rather to discuss and assess how the existing economic system could be reformed in order to curb critiques that might lead to its transformation - that is through a significant state intervention in the market. Although Bowen (2013 [1953]) stressed that the 'doctrine of social responsibility . . . is far from a panacea' (p. 7), he emphasized that 'we do and must depend ... on [businessmen] assuming a large measure of responsibility if the economic system of free enterprise is to continue to prosper' (p. 5). This, he maintained, would be in everyone's best interest since 'it is the desire and intention of the American people to retain this type of [capitalistic] system' (Bowen, 2013 [1953]: 7).

Bowen (2013 [1953]) hesitated to suggest more fundamental changes in workers' conditions, emphasizing that a 'workable system of ethical precepts' could only be developed through the process of 'thoughtful and patient discussion among persons who represent the several parties at interest, who are experienced in the practical problems of business life, and who are trained in ethics, economics, law, and other relevant disciplines' (p. 193). Thus, Bowen instead articulated the 
question of workers' security and fairness as one of investment in workers' effectiveness, urging businessmen to consider the matter on a cost-benefit basis. Rhetorically, Bowen (2013 [1953]) thus asked if it was 'worthwhile for a company to spend a million dollars for improvements in safety which, on an actuarial basis, would be calculated to reduce serious injuries by one per year?', answering that 'thoughtful ... discussions of such questions by interested parties ... might result in the achievement of a more satisfying balance between wages and working conditions and benefits' (p. 211).

We argue that Bowen's discourse on the social responsibilities of businessmen constituted a pragmatic strategy that, from the early 1950s onwards, enabled the CSR discourse to proliferate within corporate capitalism. We also suggest that a key condition for the emergence and success of the CSR discourse was its emphasis on personal ethics over regulation and redistribution. However, from the perspective of Kazmi et al. (2016), this emphasis could be viewed as constituting a 'condition of impossibility', insofar as it hinders CSR from becoming a new spirit of capitalism.

\section{Final remarks}

In this article, Boltanski and Chiapello's assimilationist thesis inspired us to explore CSR's emergence and its relationship to the social gospel. Foucault's genealogy spurred us to trace the history of modern CSR further back than its conventional starting point, Bowen's SRB from 1953. Foucault's fine-grained approach to discourse offers an analytical supplement to Boltanski and Chiapello's more general historical model, which Parker (2013) characterizes as de-contextualized and as assuming a 'meta-theoretical status' that 'explains all observations' (p. 17).

Foucault (2001) eschewed a priori conceptualizations and overarching models of historical development, preferring to describe the contingent and accidental trajectory of events and developments in their singularity: 'So many things can be changed, being as fragile as they are, tied more to contingencies than to necessities, ... more to complex but transitory historical contingencies' (p. 458). Compared to Boltanski and Chiapello's overarching dialectical framework, Foucault (1978) offered a complex analytics of the emergence, displacement and gradual transformation of discursive elements: 'We must not imagine a world of discourse divided between . . . the dominant discourse and the dominated one, but as a multiplicity of discourse elements that can come into play in various strategies' (p. 100). 
Our analysis evidences such displacements and their tactical re-articulation in early and more recent CSR discourse. The emphasis on ethical personality might be the most significant continuity between the social gospel and CSR, as evinced in the notions of spiritual nourishment, human growth and, later, self-fulfilment. Gladden (1894) maintained that helping workers achieve more achieve more fulfilling lives was the most Christian thing industrialists could do (p. 307), while Addams (1899) underlined the need to foster a 'higher type of character' (p. 462), Ely (1889) stressed that workers should realize 'the largest growth which is possible for them' (p. 124), and, finally, Bowen (2013 [1953]) called for ensuring that employees' development was 'commensurate with their potentialities' (p. 41).

In contemporary CSR the notion of 'human growth' seems to gradually transform into an individualized obligation to develop one's own entrepreneurial spirit and 'employability' (Boltanski and Chiapello, 2005: 324). According to Boltanski and Chiapello (2005: 324), employees' ethical obligation is no longer related to social ethics or a collaborative 'brotherhood' but aimed to ensure 'the flourishing of the self' by investing in one's own competencies and calculating how to maximize network connectivity.

A series of continuities has been established starting from the social gospel's articulation of Christian ethics as the self-sacrificial service of society in the name of industrial peace, and moving towards later CSR notions of corporate moral personhood and the voluntary assumption of business ethics. We situated Bowen as the oblique link in the discursive passage that spanned from a discourse proclaiming that cultivating 'character' would regenerate industrialism to early CSR thinkers' construction of the businessman as an ethical subject that could turn corporations into morally conscious beings. The ensuing discursive strategy steers CSR away from issues of distributional justice and fundamental changes in capitalist production towards personal ethics and voluntary CSR actions.

\section{References}

Abend, G. (2014) The Moral Background: An Inquiry into the History of Business Ethics. Princeton, NJ: Princeton University Press.

Acquier, A., Gond, J.P. and Pasquero, J. (2011) 'Rediscovering Howard R. Bowen's Legacy', Business \& Society 50(4): 607-46. 
Addams, J. (1895) 'The Settlement as a Factor in the Labor Movement', in J. Addams (ed.) Hull-House Maps and Papers, pp. 183-204. New York: Crowell.

Addams, J. (1899) 'A Function of the Social Settlement', The ANNALS of the American Academy of Political and Social Science 13(3): 33-55.

Addams, J. (1902) Democracy and Social Ethics. New York: Macmillan.

Addams, J. (1905) ‘Problems of Municipal Administration', American Journal of Sociology 10(4): 425-44.

Addams, J. (1930) 'Education by the Current Event', The Survey 1: 461-4.

Bell, E., Taylor, S. and Driscoll, C. (2012) 'Varieties of Organizational Soul: The Ethics of Belief in Organizations', Organization 19(4): 425-39.

Boltanski, L. and Chiapello, E. (2005) The New Spirit of Capitalism. New York: Verso Books.

Boltanski, L. and Thévenot, B. (1991) De La Justification: Les Economies De La Grandeur. Paris: Gallimard. Bowen, H. R. (2013 [1953]) Social Responsibilities of the Businessman. lowa City, IA: University of lowa Press.

Brooks, S. (2010) 'CSR and the Strait-Jacket of Economic Rationality', International Journal of Sociology and Social Policy 30(11/12): 604-17.

Canning, J. P. (1980) 'The Corporation in the Political Thought of the Italian Jurists of the Thirteenth and Fourteenth Century', History of Political Thought 1(1): 9-32.

Carroll, A. B. (1999) 'Corporate Social Responsibility: Evolution of a Definitional Construct', Business \& Society 38(3): 268-95.

Carroll, A. B., Lipartito, K. J., Post, J. E., et al. (2012) Corporate Responsibility: The American Experience. Cambridge: Cambridge University Press.

Chiapello, E. (2012) 'Capitalism and Its Criticisms', in P. du Gay and G. Morgan (eds) New Spirits of Capitalism? pp. 71-73. Oxford: Oxford University Press.

Christiansen, C. (2015) Progressive Business: An Intellectual History of the Role of Business in American Society. Oxford: Oxford University Press.

Colle, S., de Henriques, A. and Sarasvathy, S. (2014) 'The Paradox of Corporate Social Responsibility Standards', Journal of Business Ethics 125(2): 177-191.

Davenport, S. (2008) Friends of the Unrighteous Mammon: Northern Christians and Market Capitalism, 1815-1860. Chicago, IL: The University of Chicago Press.

Eddy, B. (2010) 'Struggle or Mutual Aid: Jane Addams, Petr Kropotkin, and the Progressive Encounter with Social Darwinism', The Pluralist 5(1): 21-43.

Ely, R. T. (1889) Social Aspects of Christianity, and Other Essays. New York: Thomas Y. Crowell Co.

Ely, R. T. (1896) The Social Law of Service. New York: Eaton \& Mains.

Ely, R. T. (1903) Studies in the Evolution of Industrial Society. New York: Macmillan. 
Evans, C. H. (2017) The Social Gospel in American Religion: A History. New York: New York University Press. Federal Council of Churches (1932) The Social Ideals of the Churches. New York: Federal Council of Churches.

Federal Council of Churches (1947) Pronouncements on Religion and Economic Life: Excerpts from Statements by Religious Bodies and Leaders. New York: Federal Council of Churches.

Fine, S. (1951) 'Richard T. Ely, Forerunner of Progressivism, 1880-1901', The Mississippi Valley Historical Review 37(4): 599-624.

Foucault, M. (1977b) 'What Is an Author', in D. F. Bouchard (ed.) Language, Counter-Memory, Practice, pp. 113-38. Ithaca, NY: Cornell University Press.

Foucault, M. (1978) History of Sexuality, vol. 1. New York: Vintage Books.

Foucault, M. (2001) 'So Is It Important to Think?' in J. Foubion (ed.) Power: Essential Works of Foucault (1954-1984), vol. 3, pp. 454-458. New York: The New Press.

Foucault, M. (2002) Archaeology of Knowledge. New York: Routledge.

Foucault, M. (2007) Security, Territory, Population: Lectures at the Collège De France, 1977-1978. London: Palgrave Macmillan.

Foucault, M. (2014) On the Government of the Living: Lectures at the College de France 1979-1980. Basingstoke: Palgrave.

Gladden, W. (1876) 'Labor and Capital', in R. T. Handy (ed.), The Social Gospel in America: 1870-1920, pp. 38-48. Oxford: Oxford University Press.

Gladden, W. (1894) Tools and the Man: Property and Industry under the Christian Law. Cambridge: The Riverside Press.

Gladden, W. (1897) Social Facts and Forces: The Factory, the Labor Union, the Corporation, the Railway, the City, the Church. New York: The Knickerbocker Press.

Gorrell, D. K. (1988) The Age of Social Responsibility: The Social Gospel in the Progressive Era, 1900-1920. Macon, GA: Mercer University Press.

Hall, P. D. (1992) Inventing the Nonprofit Sector and Other Essays on Philanthropy, Voluntarism and Nonprofit Organizations. Baltimore, MD: John Hopkins.

Handy, R. T. (ed.) (1966) The Social Gospel in America: 1870-1920. Oxford: Oxford University Press.

Heald, M. (1970) The Social Responsibilities of Business: Company and Community 1900-1960. Cleveland, $\mathrm{OH}$ : Case Western Reserve University.

Kazmi, B. A., Leca, B. and Naccache, P. (2016) 'Is Corporate Social Responsibility a New Spirit of Capitalism?' Organization 23(5): 742-62.

Marens, R. (2008) 'Recovering the Past: Reviving the Legacy of the Early Scholars of Corporate Social Responsibility', Journal of Management History 14(1): 55-72. 
Moura-Leite, R. C. and Padgett, R. C. (2011) 'Historical Background of Corporate Social Responsibility', Social Responsibility Journal 7(4): 528-39.

Parker, M. (2013) 'Beyond Justification: Dietrologic and the Sociology of Critique', in P. du Gay and G. Morgan (eds) New Spirits of Capitalism? pp. 1-21. Oxford: Oxford University Press.

Quandt, J. B. (1973) 'Religion and Social Thought: The Secularization of Postmillenialism', American Quarterly 25(4): 390-409.

Rader, B. G. (1966) 'Richard T. Ely: Lay Spokesman for the Social Gospel', The Journal of American History 53(1): 61-74.

Rauschenbusch, W. (1914) Christianizing the Social Order. New York: Macmillan.

Rodgers, D. T. (1982) 'In Search of Progressivism', Reviews in American History 10(4): 113-32.

Shamir, R. (2004) 'The De-Radicalization of Corporate Social Responsibility', Critical Sociology 33(3): 669-89.

Villadsen, K. (2018) 'Jane Addams' Social Vision: Revisiting the Gospel of Individualism and Solidarity', American Sociologist 49(2): 218-41.

Ward, H. F. ed. (1912) The Social Creed of the Churches. New York: Eaton \& Mains.

Weber, M. (1905) The Protestant Ethic and the Spirit of Capitalism. London: Unwin Hyman.

\section{Author biographies}

Kristian Quistgaard Steensen received his Master's in Political Management and Communication from The Copenhagen Business School. His Master Thesis explored the genealogy of modern corporate social responsibility in the context of North America. Steensen is currently working as a researcher at The Danish Evaluation Institute, EVA, focusing on the impact of organisation, management and political reform in education.

Kaspar Villadsen is Professor at the Department of Management, Politics and Philosophy, Copenhagen Business School, Denmark. His research revolves around Michel Foucault's authorship, technology, organizations and the relationship between state and civil society. He has published the book State Phobia and Civil Society (with Mitchell Dean, Stanford University Press, 2016). Villadsen's work has appeared in journals like Economy and Society, Human Relations, Theory, Culture \& Society, American Sociologist and Organization.

ORCID iD: Kaspar Villadsen https://orcid.org/0000-0002-9966-942X 